\title{
Questioning Facilities Management in Higher Education in Egyptian Context for Better Decision-Making Process of Funding Allocation
}

\author{
Mona Mohamed Abd Elghany ${ }^{1} \&$ Reem Aly Elharakany ${ }^{2}$ \\ 1 Associate Professor in Marketing and International Business Department, College of Management \& \\ Technology, Arab Academy for Science \& Technology, Alexandria, Egypt \\ ${ }^{2}$ Senior Lecturer in Financial and Accounting Department, College of Management \& Technology, Arab \\ Academy for Science \& Technology, Alexandria, Egypt \\ Correspondence: Mona Mohamed Abd Elghany, Associate Professor in Marketing and International Business \\ Department, College of Management \& Technology, Arab Academy for Science \& Technology, Alexandria, Egypt. \\ E-mail: mabdelghany2000@gmail.com
}

Received: March 30, 2017

Accepted: May 18, 2017

Online Published: June 7, 2017

doi:10.5539/ijbm.v12n7p129

URL: https://doi.org/10.5539/ijbm.v12n7p129

\begin{abstract}
The quality of education is influenced by the managerialization of the universities, which refers to the introduction of substantial changes in the decision-making processes of the academic institutions, and the application of renewed information systems along with new managerial methodologies to restructure the organisational strategic relationships with stakeholders. This paper proposes a questionnaire to assess the importance of facilities in universities according to their financial budget consumed value. Semi Structured Interviews were conducted with the heads of logistic and financial departments in Egyptian universities, twenty public universities and twenty-three private universities, in order to identify criteria for the most significant university's facilities and appealing infrastructure that contributes to the quality of education.
\end{abstract}

Keywords: decision-making process, facilities management, higher education, surveying approach

\section{Introduction}

Managerialization implies the combination of management knowledge and practices through the application of an instrumental logic with progress-oriented thoughts for the governance and controlling of organizations to effectively achieve its goals and objectives (Maier \& Meyer, 2011; Cunliffe, 2009). The abundance of data makes it difficult to find the relevant, exact and useful information necessary to the higher education decision-making process (Susnea, 2013). Surveying can portray an approach for analysing and solving complex problem through investigation and policy design, and thus helping in the decision making process related to quality in higher education based on facility management. Hence, related conducted studies in educational sector will be presented and the concluding section will summarize the implications of the theoretical previous work reviewed and the piloted interview and resultant questionnaire.

\section{Background}

The Quality of Education is considered as one of the vital determinants of national competitiveness in the global era, which is derived from the blend of superb learning process and public satisfaction in the service delivered (Hanasya, Abdullah, \& Warokka, 2011). Service quality results in customer satisfaction (Zeithaml \& Parasuraman, 1996; Zeithaml \& Bitner, 2000). Most literatures about service quality and satisfaction often used these terms interchangeably (Gwynne, Devlin, \& Ennew, 2000), with the basic theory, performance measure approach (Cronin \& Taylor, 1994).

Customer satisfaction is the ultimate goal of all organizations including higher education sector (Razavi, Safari, $\&$ Shafie, 2012). The perception of quality is multilateral (Gerson, 1993). Customer is called stakeholder in the context of higher education, where stakeholders are those groups having various interests in one university (Moraru, 2012). Quality in Higher Education is viewed from different stakeholders' perspectives; parents refer to quality in relevance to input through schools' ranking and universities' reputations and output through employability and academic placement. On the other hand, students denote quality in relevance to the educational process through courses and teaching. While faculty members recognize quality in relevance to the 
whole education system, i.e. input, process and output, and employers regard quality as primarily the skill set that the graduates bring to the workplace.

Researchers have shown that absence and/or inadequacy of facilities have great influence on the performance of both students and lecturers, in higher education institutions. Facilities are defined materials developed and designed to serve specific and precise purposes. In the educational institutions system, there are many multiple types of facilities, which facilitate educational process (Knirk, 1992).

Facilities can be divided into two types physical and non-physical facilities. Educational infrastructures are the physical assets and facilities, which contribute directly or remotely to the process of education. The physical assets and facilities development in higher education is quite complicated and cost intensive. It includes provision centres, hostels, building, staff quarters, classrooms, laboratories, libraries, health centres, and sport facilities. Managing mentioned facilities on high level of quality right from the planning level, through the development and implementation, guarantee effective realization of goals in educational institutions (Knirk, 1992).

In 1994, Bon et al. described the continuous improvement in measuring performance of infrastructure. They mentioned that this would bring additional value, in regards of many positive points, to the educational institution. They viewed that the continuous improvement can be presented by a feedback loop, which could open the door for incremental improvement. They proposed that the main goal of measuring performance of facilities and physical assets is to integrate facilities and physical assets into more faster educational activities and on improved level.

Later, Enaohwo (2003) insisted that the quality assurance of institutional physical assets and facilities could only be guaranteed if guidelines are followed. This means that infrastructural development must make provision for adaptability or alteration probability, flexibility in user demands, accessibility to students, staff and society in reference to aesthetic and clean environment.

Investigations into the process through which potential students can determine their choice of university have increased. The impact of facilities on student choice of university was discussed in a research done by Price, Matzdorf, Smith and Agahi (2003). Practical reasons of sample size dictated the use of a questionnaire based survey, in consultation with forum members. A survey instrument was designed and piloted on the 1999 student intake. A total of 87 closed questions sought rankings of importance of questions in a five Likert scale. A total of twelve questioning modules were included about: type of university, reputation of town/city, accommodations, learning, facilities, university security, transport, social facilities, sporting facilities, childcare facilities, and university environment. All responses were coded in 2000 and 2001 then analysed. The first seven items are presented in table (1) for the average rating of 4 or higher in the two surveys. The authors concluded that it is quite plausible that respondents to the questionnaire attached greater importance to factors they were more satisfied with. The students' choice is what university must have if it is to attract students. Many facilities can differentiate a particular institution.

Table 1. Average ratings of 4 or higher in 2 years surveys

\begin{tabular}{lllll}
\hline Item & 2000 average & 2000 ranking & 2001average & 2001ranking \\
\hline Had the course wanted & 4,84 & 1 & 4.8 & 1 \\
Availability of computers & 4.48 & 2 & 4.41 & 2 \\
Quality of library facilities & 4.47 & 3 & 4.41 & 3 \\
Good teaching reputation & 4.35 & 4 & 4.29 & 4 \\
Availability of quiet area (e.g. library) & 4.23 & 5 & 4.22 & 5 \\
Availability of self-study area & 4.16 & 6 & 4.21 & 6 \\
Quality of public transport & 4.07 & 7 & 4.13 & 7 \\
Friendly attitude toward students & 4.05 & 8 & 4.04 & 8 \\
Prices at catering outlets & 4.01 & 9 & 4.00 & 13 \\
Cleanliness of accommodation & 4.00 & 10 & 3.92 & 15 \\
\hline
\end{tabular}

Source: Price, Matzdorf, Smith \& Agahi, 2003. 
In 2005, William Daigneau, vice president and chief facilities officer at the University of Texas, identified five mega trends for university facilities managers to consider:

\section{1) Society changes and more specifically the demographics of students}

Facilities Managers must grasp this and integrate their institutional strategy and institutional identity into their physical resources and maintenance regimes.

\section{2) Economics, Access and Efficiency}

To achieve a more accessible and efficient educational system, higher educational institutions must understand their target market and the barriers that students face in gaining access and in succeeding in their studies.

\section{3) Technology and Innovation}

Students are increasingly adept at using technology, especially in terms of mobile platforms, and they will soon demand ease of access, reliable technical support, speedy responses from academics and opportunities to engage interactively with peers, academic and professionals within their field of study. More and more virtual spaces are created in which lectures can take place at any time and students have the freedom to listen and interact at their own convenience.

\section{4) Government and its role in being accountable}

Facilities Managers must therefore consider government's impact on academic offerings and if the received subsidies will be sufficient in creating an enabling environment.

\section{5) Environmental Issues and Sustainability}

When taking into account sustainable development concepts in the buildings and facilities, facilities managers should be relying on expertise that considers the environmental impact of the buildings, by means of a team consisting of architects, engineers, operations personnel and maintainers.

Another study conducted among the most important management oriented higher education associations in the United States, an increasing number of higher education leaders identified that the challenges associated with "aging and expanding facilities" represent one of the top change drivers in the field, exceeded via insufficient financial resources, technological change and changing student demographics (Marmolejo, 2007). In the same report, "insufficient facilities" are also considered among the top threats to the success of higher education. The study concluded that a call to action should be taken place and additionally the recognition that leadership is defined as a key ingredient would ensure higher education's future success and help mitigate its threats (Goldstein, 2006). Two of these change drivers, resource scarcity and information technology, are figured as well in the top ten critical issues that higher education facilities professionals face, according to The Association of Higher Education Facilities Officers in the United States (see Table 2). There is no question that confronting the changing needs and means for delivering education, institutional planners and managers need to reconsider the way higher education facilities are designed, planned and managed.

Table 2. Top Ten critical higher education facilities

\footnotetext{
Top Ten Critical Higher Education Facilities Issue
}

\begin{tabular}{llll}
\hline 1) & Resource scarcity and affordability; & 6) & Facility reinvestment and total cost of ownership; \\
2) Performance measurement and accountability; & 7) & Workforce issues; \\
3) Customer service; & 8) & Sustainability; \\
4) Information technology; & 9) & Energy resource management; \\
5) Developing the laboratory and classroom of the future; & 10) & And safety, security and business continuity. \\
\hline
\end{tabular}

Source: APPA (Association of Higher Education Facilities Officers) (2006), University Facilities Respond to the Changing Landscape of Higher Education, APPA, Washington, DC.

Makhanya (2010) demonstrated that trends in higher education have indicated significant growth from $19 \%$ in year 2000 to $26 \%$ in year 2007 . This represents $53 \%$ increase in the number of students. To address these increasing demands the author indicated a growing private higher education section with almost $30 \%$ of the global students enrolled in such institutions. Facilities management is increasingly becoming a critical managerial field at the operation and strategic level of management. Therefore, the author suggested that facilities managers and staff in higher education must be dynamic, skilled, analytical thinkers. He also proposed 
that facilities managers should be well informed about internal and external environments of the higher education institution to which they are hired in the following context:

- External context of facilities management:

- Management will require that higher education institutions thoroughly understand the vital role of facilities management within their institution.

- Facilities managers must understand that they are managing a dynamic and increasingly demanding field.

- Facilitates managers must understand the impact of external trends on how they strategically and operationally manage facilities.

- External governance of facilities management:

- Facilities managers must have an active role in strategy by providing inputs on how such strategies will have impact on the facilities of the institution.

- It is important that managers at executive management support the chief role of facilities and allow space to creative and innovative exploration.

- Facilities managers must identify weakness and opportunities to make positive contribution to the institution.

- Academic managerial positions must include facility managers in their planning and vice versa.

Recently, the Quality Standard QS Stars university rating system is a system that provides a comprehensive framework that can be used to rate and compare universities' performance using a broad spectrum of criteria. Categories used are relating to teaching, research, graduate employability and internationalization. The system also considers specialist and advanced criteria, as well as a set of criteria relating to the learning environment through which, universities can receive a total score out of 100, compiled from the following:

- Sport facilities: Universities are assessed on the sports facilities they offer with a maximum score of 20 based on providing swimming pool, fitness gym, and indoor sports court, outdoor sports pitch, athletic tracks, stadium, full time coach or dedicated sport medical staff.

- Medical facilities: Universities are appraised based upon medical facilities they offer with a maximum score of 10 based on providing medical campus centre, full time qualified medical doctor, full time nurse per every 3000 students.

- Student societies: Universities are evaluated on active student societies with a maximum of 10 points.

- Student accommodation: Maximum points of 20 are awarded to universities, which offer enough rooms in students' residences to accommodate all first-year undergraduate students.

- IT infrastructure: A total of 20 points are given for universities that have one computer per every five students, a Wi-Fi access across $90 \%$ of the campus.

- Library facilities: A score 20 points is dedicated to universities, which can claim three new library catalogues entry per student over the previous year.

\section{Directed Survey}

This research paper conducted the survey approach, which provides a detailed description of trends, attitudes, or opinions of a population by studying a sample of that population. Fowler (2009) illustrated that the surveying approach involves cross-sectional and longitudinal studies using questionnaires or semi-structured interviews for data collection with the intent of generalizing from a sample to a population.

Egypt has the largest overall education system in the Middle East and North Africa and it has been actively expanding since the early 1990s. The Egyptian government has recently given high priority to improve higher education as it permits the chance to make Egypt internationally competitive. While the Egyptian higher educational sector has focused on the trajectory of steady modernisation, efforts are becoming more determined on the quantifiable and measurable qualities related to economic competitiveness. With the steady growth in population in Egypt, higher education acts as a pivotal player in social stability (LaGraffe, 2012); external efforts have been yet incapable of the inspiration of an operational notion of employability on reality so that meaningful principles of quality education could be developed. Hence, the essence of the study emerged for better decision-process making for effective allocation of resources especially in the presence of the economic challenges Egypt is facing after the revolution of 2011. 
The study begins with qualitative open-ended interviews to collect detailed views from participants and then, in a second phase, proposes a questionnaire in order to assemble the most effective service facility factors that contribute to the perceived quality in Higher Education. The data collection instruments consisting of observation, semi-structured interviews and questionnaire, shown below, prove advantageous for determining the criteria that should be prioritised in funding allocation of facilities in universities. This study considered only Egyptian large universities. Additionally, the management of facilities in those universities was the chief concern in order to achieve a sustainable funding strategy that would support its long-term reform and development objectives. Former statistics had shown how researching on higher education in Egypt will provide reliable results worldwide.

\section{Facility Manager Interview}

1 Please identify your educational institution in addition to your affiliation with it;

2 How long have you been working in the institution?

3 Illustrate how the university budget is developed and the steps followed in working with the university committee and department chairs on budget development, implementation, and oversight;

4 How the university ensures that budgets are managed effectively and respond to for proposals and what revenue enhancement initiatives have been undertaken. In this context, demonstrate the most affecting facilities and their associated factors that should be assigned the priority while allocating funds for budget plan in the following tables;

Please rank in order of $1-5$, the contribution of the following on the quality of the service facilities (1 least important, 5 very important)

\begin{tabular}{|l|l|}
\hline Service Facility Factor & Ranking \\
\hline & \\
\hline & \\
\hline & \\
\hline
\end{tabular}

How does the spending on the above mentioned facility factor relate to the quality of the service facility? Please fill in the following table:

\begin{tabular}{|l|l|l|l|l|l|}
\hline $\begin{array}{l}\text { \% increase in spending } \\
\text { on service facility factor }\end{array}$ & $\begin{array}{l}\text { None } \\
(0-10)\end{array}$ & $\begin{array}{l}\text { Small } \\
(10-30)\end{array}$ & $\begin{array}{l}\text { Average } \\
(30-60)\end{array}$ & $\begin{array}{l}\text { Good } \\
(60-80)\end{array}$ & $\begin{array}{l}\text { Excellent } \\
(80-100)\end{array}$ \\
\hline 0 & & & & & \\
\hline 0.25 & & & & & \\
\hline 0.5 & & & & & \\
\hline
\end{tabular}




\begin{tabular}{|l|l|l|l|l|l|}
\hline 0.75 & & & & & \\
\hline 1.0 & & & & & \\
\hline
\end{tabular}

5 Indicate to which extent your budget plan is consistent and integrated with the university academic plan and consequently with the capital campaign goals;

6 General comments, and suggestions for improving Budget Plan Allocation for Services.

\section{Refined Questionnaire}

\section{Dear Respondent}

You are invited to participate in this survey, which provides an opportunity to reflect on your experience with facilities services at Your University. Please take a few minutes today to respond to this questionnaire. Your participation in this survey is voluntary. Kindly note that your responses will be kept confidential. Survey results will be aggregated as to protect the privacy of the respondent. The results will be analysed and forwarded to the Facilities Department to improve the budget funding allocation to resources.

\section{Regarding each Facility Criterion, please indicate your level of agreement for each of the following} statements to its importance in budget funding allocation:

\begin{tabular}{|c|c|c|c|c|c|}
\hline Statements in Alphabetical Order & $\begin{array}{l}\text { Strongly } \\
\text { Agree }\end{array}$ & Agree & $\begin{array}{l}\text { Not } \\
\text { Applicable }\end{array}$ & Disagree & $\begin{array}{l}\text { Strongly } \\
\text { Disagree }\end{array}$ \\
\hline \multicolumn{6}{|l|}{$\begin{array}{l}\text { Accessibility of portable water, toilets (quality of the toilet rooms, } \\
\text { separate toilet for males and females) }\end{array}$} \\
\hline \multicolumn{6}{|l|}{ Accessibility to Computer Clusters } \\
\hline \multicolumn{6}{|l|}{ Accessibility to functional photocopy machines } \\
\hline \multicolumn{6}{|l|}{$\begin{array}{l}\text { Attractiveness of the university compound and fencing in terms of } \\
\text { buildings' condition encompassing university principal's office (access } \\
\text { to computer, telephone, guest chairs, shelves, shutter), staff rooms (chairs, } \\
\text { tables and shelves), }\end{array}$} \\
\hline \multicolumn{6}{|l|}{$\begin{array}{l}\text { Audio Tape players, CD/DVD players, and TV set for media and } \\
\text { educational purposes }\end{array}$} \\
\hline \multicolumn{6}{|l|}{ Availability of Printing \& Photocopying Service in the Library } \\
\hline \multicolumn{6}{|l|}{ Availability of Silent Study Areas } \\
\hline \multicolumn{6}{|l|}{$\begin{array}{l}\text { Bookstore for providing Text books, Reference books, and Dictionaries, } \\
\text { and also Teaching guides and manuals }\end{array}$} \\
\hline \multicolumn{6}{|l|}{$\begin{array}{l}\text { Classrooms Convenience (floors, walls, and roofs, shutter, student seats, } \\
\text { file cabinet, whiteboards, space) }\end{array}$} \\
\hline \multicolumn{6}{|l|}{ Cleanliness (Waste Cans for Trash, Garbage \& Recycling) } \\
\hline \multicolumn{6}{|l|}{ Coffee Cart near the library entrance/ Cafeteria/ Dining Areas } \\
\hline \multicolumn{6}{|l|}{ Computer devices for staff members, administrators and students } \\
\hline \multicolumn{6}{|l|}{ Disability Service/ Accessibility / Handicapped Improvements } \\
\hline \multicolumn{6}{|l|}{ Ease of Access to Wide Range of Course Books/ Core Texts and Research } \\
\hline \multicolumn{6}{|l|}{ Hive (taking into consideration online resources) } \\
\hline \multicolumn{6}{|l|}{$\begin{array}{l}\text { Efficient overhead projector and LCD Liquid Crystal Display for } \\
\text { educational purposes }\end{array}$} \\
\hline \multicolumn{6}{|l|}{ Follow Maintenance \& Repairing System (Electrical, Energy, Sustainable } \\
\hline \multicolumn{6}{|l|}{ Practices) } \\
\hline Functionality of pedagogical centre & & & & & \\
\hline
\end{tabular}




\begin{tabular}{llll}
\hline Statements in Alphabetical Order & $\begin{array}{l}\text { Strongly } \\
\text { Agree }\end{array}$ & $\begin{array}{c}\text { Agree } \\
\text { Not } \\
\text { Applicable }\end{array}$ & $\begin{array}{l}\text { Disagree } \\
\text { Strongly } \\
\text { Disagree }\end{array}$ \\
\hline Laboratory equipment with adequacy of ICT aids' application & & &
\end{tabular}

Landscaping (Outdoor Space \& Seating, Side Walks Paths, Grass/ Tree/

Plant Areas)

Layout of Buildings/Stairs/Offices (welcoming entrance, auditoriums/ meetings areas, enough signage inside and outside, well-marked/has lots of signs, wide stairs, well connected and adjacent), additionally offering Dormitories for Students

Music instruments for personal and social development

Parking Lots (well designed \& good lighting to ease Traffic Flow and circulation)

Presence of printing service

Provision of Buses for Staff \& Students Transportation

Provision of Comfortable Seating with Low Level Tables, Well-Organized

Book Shelves, Proximity of Books \& Convenience of Library

Environment (Lighting, Temperature, Power Sockets \& Wireless

Connection for the Access of Online Resources Service)

Provision of Healthcare services (sanitary materials such as provision of first aid in case of accidents, availability of medication)

Recruitment of Qualified Staff for Every Facility

Security (Presence of Security Personnel and Cameras to grant Safety with front desk monitoring \& Control loitering)

Sport capital (resources such as playgrounds, changing rooms, bathrooms, etc., purchasing of tools \& its maintenance)

Stationary materials such as: papers, notebooks, chart and graph papers, pens, pencils and others, besides Teaching aids such as white boards,

markers, etc.

\section{Demographic Data}

Age Group:

$€ 25-34$

$€ 35-44$

$€ 45-55$

$€$ over 55

Gender:

$€$ Female

$€$ Male

Highest Level of Education Completed:
$€$ School Graduate
$€$ College Graduate
$€$ Post Graduate Degree

Which of the following best describes your role in the university?
$€$ Upper Management
$€$ Middle Management
$€$ Junior Management
$€$ Consultant
$€$ Other Please Specify

How long have you been working in the institution?

$€$ Less than 5 years 
$€ 5$ to 10 years
$€ 10$ to 20 years
$€$ Over 20 years

What is your current monthly income?

$€$ Less than 5000 Egyptian pounds

$€ 5000$ to 10000 Egyptian pounds

$€ 10000$ to 20000 Egyptian pounds

$€$ Over 2000 Egyptian pounds

$€$ Would rather not to say

The institution you work for is in which of the following:

$€$ Public Sector

$€$ Private Sector

\section{Conclusion}

This research paper examined previous effort made to investigate the importance of the facility management in higher education. All previous studies revised in this paper proved that one of the key important factors and aspect of efficiency, in terms of increasing quality of higher education, are its practical component, which personified in form of facilities. Libraries, computer labs, sports facilities, student accommodation and medical facilities seem to be the utmost significant criteria used when comparing university performance. Investment in facilities needs to be organized and facilities managers in higher education should be dynamic, skilled, and analytical thinkers. The presented questionnaire acts as a supportive method in order to make the right decision-making process when managing facilities. For further research, the resultant questionnaire will be distributed then analysed using statistical tools such as SPSS program in terms of percentages, frequencies, means and grand means.

\section{References}

Bon, R., McMahan, J. F., \& Carder, P. (1994). Property Performance Measurement: From Theory to Management Practice. Facilities, 12(12), 18-24.

Cronin Jr, J. J., \& Taylor, S. A. (1994). SERVPERF versus SERVQUAL: Reconciling performance-based and perceptions-minus-expectations measurement of service quality. The Journal of Marketing, 125-131. Retrieved from http://www.jstor.org/stable/1252256

Cunliffe, A. L., (2009). A very short, fairly interesting and reasonably cheap book about management. London: SAGE.

Daigneau, W. A., (2005). Planning, Designing and Managing Higher Education Institutions. OECD Publishing.

Enaohwo, J. O., (2003). Strategies for achieving and maintaining quality assurance in education, Paper presented at the 18th Annual Congress of the Nigerian Academy of Education, 5(4), 211-223.

Fowler, F. J., (2009). Survey research methods (4th ed.). Thousand Oaks, CA: Sage.

Gerson R. F. (1993). Measuring customer satisfaction: A guide to managing quality service. Menlo Park: Crisp Publications.

Goldstein, P. J., (2006). The Future of Higher Education: A View from CHEMA. Council of Higher Education Management Associations, Washington, DC.

Gwynne, A. L., Devlin, J. F., \& Ennew, C. T. (2000). The zone of tolerance: insights and influences. Journal of Marketing Management, 16(6), 545-564. http://dx.doi.org/10.1362/026725700785045921

Hanaysha, J., Abdullah, H. H., \& Warokka, A. (2011). Service quality and students' satisfaction at higher learning institutions: The competing dimensions of Malaysian Universities' competitiveness. Journal of Southeast Asian Research, 1. http://dx.doi.org/10.5171/2011.855931

Knirk, F. G. (1992). Facility Requirements for Integrated learning system. Educational Technology, 32(9), 26-32.

LaGraffe, D. (2012). The Youth Bulge in Egypt: An Intersection of Demographics, Security, and the Arab Spring. Journal of Strategic Security, 5(2). 
Maier, F., \& Meyer, M. (2011). Managerialism and Beyond: Discourses of Civil Society Organization and Their Governance Implications. Voluntas, 22, 4.

Marmolejo, F. (2007). Higher education facilities: Issues and trends. Retrieved May 24, 2012 from www.oecd.org/ dataoecd/17/59/38168377.pdf

Moraru, L. (2012). Academic internal stakeholder condition: A comparative approach. Procedia-Social and Behavioral Sciences, 69, 54-72.

Price, I., Matzdorf, F., Smith, L., \& Agahi, H. (2003). The impact of facilities on student choice of university. Facilities, 21(10), 212-222.

Razavi, S. M., Safari, H., \& Shafie, H. (2012). Relationships among Service Quality, Customer Satisfaction and Customer Perceived Value: Evidence from Iran's Software Industry. Journal of Management and Strategy, 3(3), 28. http://dx.doi.org/10.5430/jms.v3n3p28

Susnea, E. (2013). Improving Decision Making Process in Universities: A Conceptual Model of Intelligent Decision Support System. Social and Behavioural Science, 76, 795-800, http://dx.doi.org/10.1016/j.sbspro.2013.04.208

Zeithaml, V. A., \& Bitner, M. J. (2000). Services Marketing: Integrating Customer Focus across the Firm. United States of America: Irwin McGraw-Hill.

Zeithaml, V. A., Berry, L. L., \& Parasuraman, A. (1996). The behavioral consequences of service quality. The Journal of Marketing, 31-46. http://dx.doi.org/10.2307/1251929

\section{Copyrights}

Copyright for this article is retained by the author(s), with first publication rights granted to the journal.

This is an open-access article distributed under the terms and conditions of the Creative Commons Attribution license (http://creativecommons.org/licenses/by/4.0/). 